\title{
Penerapan Behavioral Parent Training untuk Menurunkan Stres Pengasuhan pada Ibu yang Memiliki Anak dengan Gangguan ADHD
}

\author{
Wanda Rahma Syanti ${ }^{1}$ \\ Fakultas Psikologi, Universitas Hang Tuah Surabaya \\ Woelan Handadari ${ }^{2}$ \\ Fakultas Psikologi, Universitas Airlangga Surabaya
}

\begin{abstract}
The study aimed to investigate empirically the effectivity of Behavioral Parent Training to reduce parenting stress in mother of ADHD children. Design of this study was quasi experiment with 2 groups, experiment and control. Participants of this study were 9 mothers of children with ADHD. This study used Parenting Stress Index-Short Form (PSI-SF), Behavioral Parent Training module, observation and interview to collect data. Analysis of this study was independent sample t-test. The result of analysis showed that behavioral parent training was effective to reduce parenting stress in mothers of ADHD children. Parenting stress in mother reduced significantly after following behavioral parent training. The findings supported the the conclusion that behavioral parent training was effective, because the content of behavioral parent training focused on increasing management stress, resource and competence of mother when dealing with their children, so there was increasing perception of mothers' competence.
\end{abstract}

Key words: behavioral parent training, mothers of ADHD children, parenting stress.

Abstrak. Penelitian ini bertujuan untuk mengetahui efektivitas behavioral parent training untuk menurunkan stres pengasuhan pada ibu yang memiliki anak dengan ADHD. Desain penelitian ini adalah eksperimen kuasi dengan dua kelompok, kelompok eksperimen dan kelompok kontrol. Partisipan penelitian ini adalah 9 orang ibu yang memiliki anak dengan ADHD. Teknik pengumpulan data dalam penelitian ini menggunakan Parenting Stress Index-Short Form (PSI-SF), modul Behavioral Parent Training, observasi dan wawancara. Analisis data menggunakan independent sample t-test. Hasil penelitian ini menunjukkan bahwa behavioral parent training efektif untuk menurunkan stres pengasuhan pada ibu yang memiliki anak dengan ADHD. Stres pengasuhan ibu menurun secara signifikan setelah mengikuti behavioral parent training. Hal ini berarti bahwa konten pelatihan behavioral parent training yang menitikberatkan pada peningkatan kemampuan ibu dalam mengelola stres dan peningkatan sumber daya, kompetensi ibu dalam menghadapi anak dan peningkatan persepsi ibu terhadap kemampuannya terbukti efektif.

Kata kunci: behavioral parent training, ibu dengan anak $A D H D$, stres pengasuhan.

Korespondensi: ${ }^{1}$ Fakultas Psikologi, Universitas Hang Tuah, Jl. Arief Rahman Hakim 150, Surabaya 60111, Telp. (031) 5945864, Fax. (031) 5946261, ${ }^{2}$ Fakultas Psikologi, Universitas Airlangga, Kampus B UNAIR - JI. Airlangga 4-6, Surabaya 60286, Telp. (031) 5032770, 5014460, Fax. (031) 5025910,Email: wanda.rahma@gmail.com', woelan.handadari@psikologi.unair.ac.id ${ }^{2}$ 


\section{PENDAHULUAN}

Attention Deficit/Hyperactivity Disorder (ADHD) merupakan suatu kondisi yang pervasif, kronis dan ditandai oleh tiga pola inti, yaitu gangguan pemusatan perhatian, hiperaktivitas dan impulsivitas (American Psychiatric Association, 2000 dalam Theule dkk., 2012). Persentase anak dengan ADHD usia sekolah di Indonesia belum diketahui secara pasti, namun gambaran data dari Unit Psikiatri Anak (Day Care) RSUD Dr. Soetomo Surabaya menunjukkan ada peningkatan jumlah pasien anak ADHD dari tahun 2000-2001 sebesar 43.33\% yaitu dari 60 anak menjadi 86 anak. Sebanyak 70\% pasien adalah anak laki-laki dan $30 \%$ adalah anak perempuan yang berusia 3 sampai diatas 12 tahun (Mulyono, 2003).

Gejala-gejala yang dialami anak dengan ADHD berpotensi untuk menimbulkan masalah yang kompleks, baik dari sisi akademik, sosial maupun secara pribadi. Anak ADHD sering mengalami kegagalan secara akademik dan mendapatkan skor yang rendah dalam testes terstandar (Hinshaw, 2001 dalam Dubbs, 2008). Anak dengan ADHD memunculkan perilaku yang bersifat mengganggu ketika berinteraksi dengan orang lain, kegagalan dalam melakukan hubungan timbal balik dengan orang lain dan adanya tendensi untuk berbuat kerusakan membuat anak dengan ADHD ditolak oleh teman-teman sebayanya. Anak dengan ADHD menunjukkan masalah psikologis, akademik, emosi dan masalah sosial yang lebih besar (Barkley, 1997 dalam Huang dkk., 2009).

Selain menyebabkan masalah bagi dirinya sendiri, gejala yang dimiliki oleh anak dengan ADHD juga memunculkan masalah bagi orangtua atau anggota keluarga yang lain. Orangtua harus menghadapi masalah perilaku yang ditimbulkan anak dengan ADHD setiap harinya. Anak dengan ADHD dilaporkan sering mengabaikan permintaan orangtua mereka, berkelahi dengan saudara-saudara dan teman sebaya mereka, sehingga orangtua harus memelihara mereka dengan kontrol dan tenaga yang lebih besar (Mulyono, 2003).

Orangtua, khususnya ibu, memiliki kecenderungan mengalami kesulitan dalam mengurus anak-anak mereka dibandingkan dengan ayah (Barkley, 1982 dalam Zarei, 2010). Salah satu faktor penyebabnya adalah seringnya ibu menghabiskan waktu dan seringnya berinteraksi pada kegiatan anak yang menyebabkan munculnya tekanan (Zarei, 2010). Ibu harus mengatasi simtom impulsivitas dan hiperaktivitas yang membuat anak dengan ADHD seringkali terlibat masalah dengan teman ataupun guru saat tidak bisa menyelesaikan tugas di sekolah (Zarei, 2010). Anak dengan ADHD sulit untuk mematuhi aturan, sulit mendengarkan saat ibu memberi informasi atau memberi instruksi dan sulit memahami tugas yang diberikan. Hal ini menyebabkan tekanan pada ibu. Selain itu ibu juga merupakan salah satu orang yang memiliki peran penting dalam pemberian dukungan sosial terhadap anakADHD (Yousefia, 2011).

Dukungan sosial penting untuk anak dengan ADHD, meliputi dukungan emosional, bimbingan dan pendampingan dalam pengerjaan tugas-tugas anak hal ini dilakukan agar anak tidak mengganggu atau merusak benda-benda di sekitarnya (Yousefia, 2011). Ibu juga dituntut untuk memberikan supervisi terus menerus pada anak karena seringnya anak mengalami cidera fisik (Erickson, 1982 dalam Dottan, 2011).

Pada kenyataannya, menjadi ibu yang menyediakan dukungan sosial dan menjadi pendamping bagi anak-anak dengan hiperaktivitas adalah hal yang sangat sulit dilakukan (Zarei, 2010). Hal ini dilatarbelakangi oleh beberapa karakteristik yang dimiliki oleh anak ADHD berpotensi menimbulkan stres pengasuhan pada orangtua. Perilaku anak yang cenderung bertindak tanpa berpikir dahulu dan hiperaktivitas menyebabkan anak dengan ADHD bertindak sesuai keinginan sendiri dan 
sulit untuk memenuhi harapan orangtua mereka. Anak dengan ADHD seringkali keras kepala, sering memerintah, memiliki temperamen yang meledak-ledak dan kurang mampu dalam mengikuti perintah orangtua (Segal, 2001; Whalen, dkk., 2006 dalam Dottan, 2011). Beberapa masalah yang telah disebutkan dan gejala-gejala yang dimunculkan anak dengan ADHD menjadi beberapa faktor yang menyebabkan munculnya stres pada orangtua (Huang, dkk, 2009).

Sebuah studi meta-analisis yang dilakukan oleh Theule (2010) menyelidiki mengenai hubungan antara stres pengasuhan pada orangtua yang memiliki anak ADHD. Studi ini melibatkan 44 studi yang telah dilakukan di kawasan Amerika Utara, Eropa bagian barat dan Asia. Hasil dari studi meta-analisis ini juga menunjukkan bahwa orangtua dengan anak ADHD mengalami stres pengasuhan yang secara signifikan lebih besar dibandingkan dengan orangtua tanpa anak ADHD. Penelitian oleh Dottan dkk., (2011) di Israel juga menunjukkan bahwa orangtua yang memiliki anak dengan ADHD mengalami peningkatan stres dibandingkan dengan kelompok kontrol yaitu orangtua tanpa anak dengan ADHD.

Peneliti melakukan wawancara awal pada ibu-ibu calon peserta yang memiliki anak dengan ADHD. Senada dengan penelitianpenelitian lain, ibu-ibu calon peserta pelatihan menceritakan stres yang dialami saat mengasuh anak dengan ADHD adalah cara mendisiplinkan dan membuat anak patuh terhadap aturan. Ibu seringkali merasa gagal karena sudah sering memerintahkan anak untuk diam atau mengerjakan tugas namun anak tetap tidak bisa diam dan tidak bisa menyelesaikan tugasnya. Ibu juga seringkali mendapatkan pengaduan dari orang lain di sekitarnya. Pengaduan dari orangtua lain jika anak mengganggu temannya di kelas dan dari saudara saat anak tidak bisa duduk tenang saat berkunjung ke rumah saudara. Hal inilah yang menyebabkan ibu seringkali merasa putus asa, tidak mampu, tidak memiliki ilmu untuk mengasuh anak, tidak memiliki pengalaman sebelumnya dan akhirnya menyebabkan ibu mengalami stres pengasuhan.

Stres pengasuhan merupakan suatu kondisi yang dirasakan oleh ibu seiring dengan meningkatnya persepsi orangtua terhadap tuntutan pengasuhan yang melebihi sumber daya yang dimiliki untuk mengurus anak-anak mereka (Deater-Deckard, 2004 dalam Theule, 2012). Ibu yang memiliki anak dengan masalah perilaku melihat diri mereka kurang memiliki pengetahuan mengenai pengasuhan, kurang memiliki kompetensi dalam pengasuhan anak, dan kurang dukungan sosial (Morgan, Robinson \& Aldridge, 2002 dalam McCleary, 1999). Studi yang pernah dilakukan untuk membandingkan orangtua dengan anak ADHD dan tanpa anak ADHD menunjukkan bahwa ibu dengan anak ADHD menunjukkan rendahnya self-efficacy mereka terhadap kemampuan mereka dalam membantu anak mereka. Studi yang pernah dilakukan oleh Barkley (dalam McCleary, 1999) menunjukkan bahwa beberapa orangtua telah mencapai keadaan parenting learned helplesness sebagai hasil dari kegagalan berulang saat mencoba mengatur perilaku anak-anak mereka (McCleary, 1999). Orangtua harus mengeluarkan usaha yang lebih besar untuk mengontrol anak mereka, merasa tidak diterima oleh anak-anak mereka, orangtua juga merasa kurang diterima dan kurang didukung oleh pihak sekolah dan guru-guru dari anak-anak mereka (Johnston \& Mash, 2001; Kim \& Yoo, 2012; Mano \& Uno, 2007 dalam Margari, 2013).

Akhir-akhir ini masalah stres pengasuhan pada orangtua dengan anak ADHD semakin menjadi perhatian, karena ditemukan bahwa stres pengasuhan menyebabkan masalah lanjutan antara orangtua dengan anak. Stres akan mempengaruhi gaya pengasuhan orangtua dan interaksi antara orangtua dengan anak. Orangtua cenderung menunjukkan perilaku verbal yang lebih agresif dengan anak-anak mereka saat berada dalam situasi penuh stres 
(Brook, dkk., 2005). Studi lain oleh Alizadeh, dkk (2007) menunjukkan bahwa orangtua yang memiliki anak dengan ADHD menunjukkan hubungan yang kurang hangat dan kurang terlibat dengan anak mereka, dan lebih sering memberikan hukuman fisik lebih dibandingkan orangtua tanpa anak dengan ADHD.

Behavioral parent training (BPT) adalah salah satu intervensi psikososial yang sering dipergunakan dan ditujukan untuk ibu yang memiliki anak dengan ADHD. Pada tahun 1998, Pelham mengulas literatur-literatur yang relevan dan menarik kesimpulan bahwa behavioral parent training merupakan sebuah intervensi yang efektif (Pelham, 1998 dalam Zwi dkk., 2012). Pelham juga menyatakan bahwa intervensi-intervensi yang berbasis perilaku (seperti behavioral parent training, behavioral classroom management dan intensive summer program-based peer intervention) terbukti menjadi intervensi yang efektif untuk ibu dengan anak ADHD (Pelham, 2008 dalam Zwi dkk, 2012). Pelham, dkk. (1998 dalam Pelham, 2008) mengulas intervensi yang dilakukan pada beberapa literatur dan menyimpulkan bahwa BPT adalah salah satu intervensi yang telah disusun dengan baik untuk anak dengan ADHD. Sonuga-Barke, dkk. (2001 dalam Pelham, 2008) memaparkan efektivitas BPT pada kelompok anak muda dengan ADHD. Huang, dkk. (2009) menguji efektivitas BPT pada orangtua dari 21 anak prasekolah dengan ADHD. Fabiano (2008) juga telah menguji efektivitas BPT pada 75 ayah yang memiliki anak dengan ADHD dan membuktikan bahwa BPT efektif untuk menurunkan stres pengasuhan.

Konten BPT tepat untuk diberikan pada peserta penelitian ini terkait dengan karakteristik anak yang mayoritas memiliki gangguan dengan hiperaktivitas. BPT cocok untuk menjawab permasalahan orangtua yang diulas di wawancara awal, dimana ibu mengeluh merasa tidak mampu, tidak memiliki kompetensi dalam mengasuh anak dengan gangguan ADHD. Ibu merasa ragu mengenai cara pengasuhan yang telah diterapkan pada anak, sehingga perlu diberi psikoedukasi dan pelatihan BPT.

\section{METODE}

\section{Desain penelitian}

Penelitian ini merupakan penelitian eksperimen dengan desain eksperimen semu (quasi experiment) dengan non-randomized pretest-post test control group design. Dalam penelitian ini, yang merupakan variabel independennya adalah BPT (BPT) dan yang merupakan variabel adalah stres pengasuhan ibuyang memiliki anak dengan ADHD.

\section{Populasi dan sampling}

Populasi dalam penelitian ini adalah ibu yang memiliki anak berusia $7^{-11}$ tahun yang mengalami ADHD yang sedang bersekolah di SD X. Diagnosis pada anak ADHD dilakukan oleh dokter anak, psikiater atau psikolog dan pendidikan ibu minimal jenjang SMP. Hal ini dimaksudkan untuk mengontrol kemampuan penerimaan materi dan mengikuti pelatihan yang akan diberikan.

Partisipan mampu diajak berkomunikasi dan memahami percakapan; belum pernah mengikuti pelatihan yang sejenis; dan bukan single parent. Hal ini dimaksudkan untuk mengontrol stres yang dialami oleh ibu. Sedangkan, sampel dalam penelitian ini akan ditentukan dari hasil pretest menggunakan skala Parenting Stress Index. Ibu yang mengalami tingkat stres sedang hingga tinggi dan bersedia menjadi partisipan untuk mengikuti kegiatan pelatihan akan masuk dalam kelompok eksperimen yang nantinya akan menjadi sampel penelitian.

\section{Pengukuran}

Alat pengumpulan data dalam penelitian ini atara lain adalah, skala Parenting Stres IndexShort Form (PSI-SF) dan modul (BPT). Kemudian alat pengumpulan data tambahan 
selama proses pelatihan adalah observasi yang dilakukan selama proses BPT, wawancara yang dilakukan dengan orangtua partisipan, lembar kerja partisipan, lembar evaluasi, dan dokumentasi. Teknik analisis data kuantitatif yang digunakan dalam eksperimen ini adalah uji asumsi data menggunakan uji normalitas dan uji homogenitas. Uji hipotesis akan menggunakan independent sample t-test.

\section{HASIL PENELITIAN}

dan menunjukkan perubahan kategori stres yang awalnya tinggi turun menjadi sedang. Partisipan JU menunjukkan penurunan skor stres pengasuhan 56 poin dan menunjukkan perubahan kategori stres yang awalnya sangat tinggi menjadi di kategori sedang.

Satu peserta pada kelompok kontrol menunjukkan nilai selisih skor yang positif, sementara tiga lainnya mendapat nilai selisih skor yang negatif. Hal ini berarti bahwa tiga peserta mengalami peningkatan skor stres

Tabel 1.

Perbandingan Tingkat Stres Sebelum dan Sesudah Intervensi

\begin{tabular}{|c|c|c|c|c|c|c|}
\hline Kelompok & Partisipan & Pretest & Kategori & Post Test & Kategori & Selisih \\
\hline \multirow[t]{5}{*}{ Eksperimen } & $A L$ & 122 & Tinggi & 106 & Sedang & 16 \\
\hline & TE & 119 & Sedang & 89 & Sedang & 30 \\
\hline & PU & 99 & Sedang & 94 & Sedang & 5 \\
\hline & SU & 122 & Tinggi & 97 & Sedang & 25 \\
\hline & JU & 149 & Sangat tinggi & 93 & Sedang & 56 \\
\hline \multirow[t]{4}{*}{ Kontrol } & $\mathrm{ZI}$ & 74 & Rendah & 86 & Sedang & -12 \\
\hline & DA & 92 & Sedang & 98 & Sedang & -6 \\
\hline & IL & 108 & Sedang & 99 & Sedang & 9 \\
\hline & IC & 85 & Sedang & 96 & Sedang & -11 \\
\hline
\end{tabular}

Berdasarkan hasil analisis deskriptif yang tersaji di tabel 1 , tingkat stres sebelum dan sesudah pelatihan pada kelompok eksperimen dan kelompok kontrol maka dapat diketahui bahwa 5 partisipan dalam kelompok eksperimen menunjukkan nilai selisih skor positif yang berkisar antara 5 hingga 56 . Hal ini menunjukkan bahwa semua peserta pelatihan pada kelompok eksperimen menunjukkan penurunan skor stres pengasuhan. Partisipan AL mengalami penurunan 16 poin dan menunjukkan perbedaan kategori stres yang awalnya tinggi turun menjadi kategori sedang. Partisipan TE mengalami penurunan 30 poin namun kategori stres tetap pada kategori sedang. Partisipan PU menunjukkan penurunan 5 poin dan kategori stres partisipan PU tetap di kategori sedang. Partisipan SU menunjukkan penurunan tingkat stres 25 poin pengasuhan, sementara satu peserta mengalami penurunan skor stres pengasuhan. Partisipan ZI mengalami kenaikan tingkat stres sebanyak 12 poin dan menunjukkan perubahan kategori stres yang awalnya rendah naik ke kategori sedang. Partisipan DA menunjukkan peningkatan skor stres pengasuhan sebanyak 6 poin namun kategori stres partisipan tetap pada kategori sedang. Partisipan IL menunjukkan penurunan skor stres pengasuhan sebesar 9 poin namun kategori stres tetap pada kategori sedang. Partisipan IC mengalami peningkatan skor stres pengasuhan sebesar 11 poin namun kategori stres partisipan tetap di kategori sedang. Hanya ada satu peserta pada kelompok kontrol yang menunjukkan penurunan tingkat stres. Analisis selanjutnya menunjukkan bahwa perubahan skor pada IL terjadi pada aspek perilaku anak, bukan pada aspek stressor yang 
berasal dari orangtua. Hal ini berarti tingkat stres menurun dikarenakan anak berperilaku lebih baik pada jeda waktu satu minggu setelah pengukuran pre-test hingga ke post tes dan tidak berhubungan dengan stressor yang berhubungan dengan kompetensi ibu dalam mengelola stres.

\section{DISKUSI}

Hasil pengujian hipotesis secara statistik menunjukkan adanya perbedaan skor stres secara signifikan pada kelompok eksperimen, jika dibandingkan dengan kelompok kontrol dan dibandingkan antara hasil pretest dengan

Tabel 2.

Data Deskriptif Kelompok Eksperimen dan Kontrol

\begin{tabular}{|c|c|c|c|c|c|c|c|c|}
\hline \multirow[t]{2}{*}{ Kelompok } & \multicolumn{4}{|c|}{ Pretest } & \multicolumn{4}{|c|}{ Post Test } \\
\hline & Min & Max & Rerata & SD & Min & Max & Rerata & SD \\
\hline Eksperimen & 99 & 149 & 122.2 & 17.8 & 89 & 106 & 95.8 & 6.4 \\
\hline Kontrol & 74 & 108 & 89.8 & 14.2 & 86 & 99 & 94.75 & 5.9 \\
\hline
\end{tabular}

Dari hasil analisis deskriptif sesudah dan sebelum pelatihan yang tersaji di tabel 2, menunjukkan bahwa skor minimum kelompok eksperimen sebelum pelatihan adalah 99 dan setelah pelatihan turun menjadi 89. Skor maksimal kelompok eksperimen sebelum pelatihan adalah 149, sedangkan setelah pelatihan turun menjadi 106. Rerata kelompok eksperimen juga menunjukkan penurunan dari 122.2 menjadi 95.8. Skor minimum pada kelompok kontrol saat pretest adalah 74 dan skor minimum saat post test naik menjadi 86 . Skor maksimal kelompok kontrol saat pretest adalah 108 dan turun menjadi 99 saat post test. Rerata skor stres pengasuhan juga mengalami kenaikan dari 89.8 menjadi 94.75 .

Selanjutnya, uji hipotesis dengan menggunakan independent sample t-test menunjukkan bahwa Ho ditolak ( $\mathrm{p}<0.005)$. Artinya ada perbedaan tingkat stres pada ibu yang memiliki anak dengan ADHD sebelum dan sesudah pemberian BPT dibandingkan dengan kelompok kontrol. Perlakuan yang diberikan pada kelompok eksperimen berhasil atau efektif untuk menurunkan tingkat stres pada peserta pelatihan. post test. Hal ini menandakan bahwa BPT efektif untuk menurunkan stres pengasuhan pada peserta di kelompok eksperimen. Efektivitas BPT dapat dilihat dari pemaparan hasil penelitian secara deskriptif, dimana kelima partisipan dalam kelompok eksperimen mengalami penurunan skor stres setelah mengikuti pelatihan BPT. Hanya satu orang peserta pada kelompok kontrol yang mengalami penurunan stres, sementara tiga peserta lainnya mengalami peningkatan stres.

Hasil selisih skor juga menunjukkan hasil positif berkisar antara 5 hingga 56 pada kelompok eksperimen, sedangkan pada kelompok kontrol, selisih skor berkisar di antara -12 hingga 9. Rerata skor stres pengasuhan kelompok eksperimen saat pretest yaitu $\mathbf{1 2 2 . 2}$ turun menjadi 95.8 pada saat post-test, sementara pada kelompok kontrol rerata skor stres justru menunjukkan peningkatan dari skor awal 89.8 menjadi 94.75 .

Efektivitas BPT juga dapat dilihat dari kategorisasi stres yang dialami ibu. Pada kelompok eksperimen, tiga dari lima peserta mengalami penurunan stres yang cukup signifikan. Partisipan JU mengalami stres pengasuhan pada kategori sangat tinggi pada saat pelaksanaan pretest turun ke kategori 
sedang setelah mengikuti pelatihan. Partisipan AL dan PU mengalami stres pengasuhan di kategori tinggi saat pretest berhasil turun menjadi kategori sedang setelah mengikuti pelatihan BPT. Hasil pada kelompok kontrol menunjukkan bahwa tiga dari empat peserta berada pada kategori stres pengasuhan sedang saat pelaksanaan pretest dan hal ini tidak berubah saat pelaksanaan post test. Satu peserta mengalami kenaikan kategori stres pengasuhan yang awalnya di kategori rendah meningkat kategori sedang saat post test.

Hasil yang didapatkan mendukung beberapa penelitian serupa yang telah dilakukan sebelumnya. Beberapa contohnya adalah penelitian dari Huang (2009) dan Chacko (2006). Hasil penelitian Huang (2009) membuktikan bahwa BPT efektif untuk menurunkan stres pengasuhan pada populasi ibu yang memiliki anak dengan ADHD di usia pra-sekolah. Hasil penelitian Chacko (2006) membuktikan efektivitas modifikasi BPT pada populasi ibu yang memiliki anak dengan ADHD. Pelatihan-pelatihan ini menjelaskan bahwa BPT mengajarkan orangtua untuk meningkatkan kemampuan dalam pengasuhan anak pemecahan masalah sehingga kemampuan ibu dalam mengelola stres pengasuhan meningkat. Kemampuan ini akhirnya berdampak pada menurunnya tingkat stres pengasuhan.

Senada dengan penelitian dari Chacko (2006), penelitian ini juga membuktikan bahwa BPT mampu menurunkan stres pengasuhan terutama stres pengasuhan yang berasal dari aspek $P$, yaitu parental distress yang dialami oleh ibu. Pelatihan yang telah dijalani ini mampu meningkatkan kemampuan ibu, mengakibatkan persepsi ibu terhadap kemampuannya meningkat dan akhirnya berdampak pada menurunnya stres pengasuhan yang dialami ibu dengan anak ADHD.

Efektivitas pelatihan juga dapat dilihat dari hasil wawancara pada saat evaluasi pelatihan. Berdasarkan evaluasi reaksi yang telah dilakukan, diketahui bahwa peserta berpendapat bahwa konten pelatihan dapat dipahami dan jelas, terutama untuk materi kedua yaitu penghargaan positif dan materi ketiga yaitu token ekonomi. Para peserta juga menilai bahwa materi-materi yang disampaikan sangat bermanfaat. Materi pertama memberi informasi pada peserta mengenai ADHD dan apa ciri-ciri yang nampak pada anak. Materi kedua mengenai cara pemberian instruksi yang tepat pada anak dan pentingnya memberi pujian juga dianggap sangat bermanfaat bagi peserta. Peserta menilai role play saat pelatihan membantu mereka dalam memahami materi, sehingga peserta cukup percaya diri saat harus menerapkan langsung di rumah. Peserta juga menilai penggunaan stiker membuat metode token ekonomi lebih efektif karena bisa menarik perhatiananak.

Pelatihan BPT juga bisa dinilai efektif karena saat ini peserta sudah mulai menerapkan konten materi di kehidupan sehari-hari. Peserta mulai menerapkan cara penyampaian instruksi pada anak yang benar dengan menggunakan instruksi singkat dan memberi pujian pada anak jika berhasil melaksanakan tugas atau perintah. Salah satu peserta sudah merasakan dampak langsung penerapan penghargaan positif. Anak partisipan menjadi lebih sering tertawa dan anak mengulang perilaku positif tersebut di lain waktu dengan cukup konsisten, setelah diberi pujian.

Seluruh peserta telah mencoba menerapkan metode token ekonomi di rumah. Dibantu oleh lembar kerja terakhir yang mereka kerjakan di saat pelatihan, para peserta telah menetapkan satu target perilaku untuk anak. Peserta diminta menargetkan perilaku yang masih bisa dicapai oleh anak, namun perilaku tersebut juga tidak terlalu memberatkan anak. Hal ini dimaksudkan agar anak merasa mampu untuk memenuhi target dari ibu, dengan mengeluarkan usaha untuk mencapainya. Seminggu setelah pelatihan, partisipan melaporkan bahwa penerapan papan token ekonomi membantu mereka dalam 
mengajarkan perilaku positif pada anak dan berhasil membuat anak mengulang kembali perilaku positif yang ditargetkan.

Aspek selanjutnya yang turut membantu efektivitas pelatihan BPT adalah ketersediaan modul bagi peserta. Hampir seluruh peserta pelatihan menilai bahwa modul yang diberikan bermanfaat dan sesuai dengan kebutuhan para peserta pelatihan. Sebagian besar peserta menilai bahwa modul yang diberikan menarik dan jelas. Peserta menilai modul yang diberikan menarik karena diberi tambahan ilustrasi gambar yang memudahkan peseta dalam membayangkan materi dalam modul. Modul membantu para peserta untuk mengingat materi yang telah diajarkan pada saat pelatihan.

BPT yang telah diterapkan pada peserta pelatihan memiliki kekurangan, yaitu BPT tidak memberi pengaruh langsung untuk menurunkan stress pengasuhan dari aspek $C$ (difficult child), stres pengasuhan yang muncul karena perilaku anak. BPT merupakan salah satu intervensi psikososial pada orangtua sehingga membutuhkan waktu dan pembiasaan untuk bisa mengubah perilaku anak sehingga stres pengasuhan dari aspek $\mathrm{C}$ bisa menurun.

\section{SIMPULAN}

Analisis data dan penghitungan secara statistik menunjukkan bahwa BPT efektif menurunkan stres pengasuhan pada ibu yang memiliki anak dengan anak ADHD. Terjadi penurunan stres pengasuhan secara signifikan pada ibu setelah mendapatkan pelatihan BPT. Konten pelatihan BPT yang menitikberatkan pada peningkatan kemampuan ibu dalam mengelola stres, peningkatan sumber daya dan kompetensi ibu dalam menghadapi anak terbukti efektif.

Perasaan ibu terhadap kompetensi dalam mengasuh anak meningkat setelah ber- partisipasi dalam BPT, self-efficacy ibu meningkat, kemampuan pemecahan masalah meningkat, ibu mulai memahami penyebab anak berperilaku sangat aktif dan akhirnya ibu lebih bertoleransi terhadap perilaku anak. Ibu memahami bahwa ada proses di otak anak yang berbeda dengan anak lainnya, sehingga ibu mengurangi ekspektasi terhadapanak mereka.

Stres pengasuhan di aspek lain yaitu aspek C (difficult child) tidak mengalami penurunan yang signifikan. Hal ini didasarkan pada konten pelatihan BPT tidak memberi intervensi langsung di aspek ini, sehingga dampak pelatihan tidak bisa langsung terlihat. Penerapan materi pelatihan secara konsisten dalam kehidupan sehari-hari memungkinkan turunnya stres pengasuhan pada aspek $\mathrm{C}$ di kemudian hari.

\section{SARAN}

Para peserta pelatihan harus terus menerapkan konten materi BPT secara konsisten di kehidupan sehari-hari. Selalu memastikan anak untuk membangun kontak mata saat akan memberikan instruksi, menggunakan kalimat positif saat memberi instruksi atau memberi tahu hal yang dilarang, dan memberikan pujian saat anak mampu menunjukkan perilaku yang diinginkan. Salah satu keterbatasan dalam penelitian ini adalah terbatasnya stres hanya ditinjau dari sisi stres pengasuhan, sedangkan ada beberapa faktor lain yang memungkinkan timbulnya stres, contohnya dari faktor ekonomi maupun dukungan pasangan. Peneliti selanjutnya diharapkan untuk bisa mempertimbangkan faktor lain yang turut berperan dalam munculnya stres pada ibu yang memiliki anak dengan ADHD 


\section{PUSTAKA ACUAN}

Alizadeh, H., Applequist, K. F. \& Coolidge, F.L. (2007). Parental Self-confidence, Parenting Styles and Corporal Punishment in families of ADHD Children in Iran. Child Abuse and Neglect, 31, 567-572.

Brook, U. \& Boaz, M. (2005). Attention Deficit and Hyperactivity disorder/Learning Disabilities (ADHD/LD): Parental characterization and Perception. Patient Education and Counseling, 57, 96100.

Chacko, A., Wymbs, B.T., Wymbs, F.A., Pelham, W.E., Swanger-Gagne, M.S., Girio, E., Pirvics, L., herbst, L., Guzzo, J., Phillips, C. \& O'Connor, Briannon. (2009). Enhancing Traditional Behavioral Parent Training for Single Mothers of Children with ADHD. Journal of Clinical Child and Adolescent Psychology, 38(2), 206-218.

Dottan, R.F., Triwitz, Y.S. \& Golubchik, P. (2011). Predictors of stress-related growth in parents of children with ADHD. Research in Developmental Disabilities, 32, 510519.

Dubbs, J.L. (2008). Parent Stress Reduction Through A Psychosocial Intervention For Children Diagnosed With Attention-Deficit/Hyperactivity Disorder. Indiana University of Pennsylvania. Dissertation. Tidak Diterbitkan.

Fabiano, G. A., Chacko, A., Pelham, W.E., Robb, J., Walker, K.S., Wymbs, F., Sastry, A.L., Flammer, L., Keenan, J.K., Visweswaraiah, H., Shulman, S., herbst, L \& Pirvics, L. (2009). A Comparison of Behavioral Parent Training Programs for Fathers of Children with Attention-Deficit/Hyperactivity Disorder. Behavior Therapy, 40, 190-204.

Huang, H.L., Lu, C.H., Chuang, S.F., Tsai, H.W., Tsai, C.H., Chao, C.C., Yang, P.C. \& Ho, T.Y. (2009). Effectiveness of behavioral parent therapy in Preschool Children with attention-deficit. Kaohsiung Journal Medical Science, 25, 357365.

Margari, F., Craig, F., Petruzzelli, M.G., Lamanna, A., Matera, E. \& Margari, L. (2013). Parents psychopathology of children with Attention Deficit Hyperactivity Disorder. Research in Developmental Disabilities, 34, 1036-1043.

McCleary, L., Ridley, T. (1999). Parenting adolescents with ADHD: evaluation of a psychoeducation group. Patient Education and Counseling, 38, 310.

Mulyono, R. (2003). Menangani Anak Hiperaktif: Panduan Orangtua dan Guru dalam Membimbing Anak yang Mengalami Gangguan Pemusatan Perhatian dan Hiperaktivitas (GPPH). Jakarta: Studia Press.

Pelham, W.E. \& Fabiano, G. A. (2008). Evidence-Based Psychosocial Treatments for AttentionDeficit/Hyperactivity Disorder. Journal of Clinical Child and Adolescent Psychology, 37, 184-214.

Theule, J., Wiener, J., Tannock, R. \& Jenkins, J.M. (2012). Parenting Stress in Families of Children with ADHD: A Meta-Analysis. Journal of Emotional and Behavioral Disorders, 21 (1), 317.

Yousef ia, S., Far, A.S. \& Abdolahian, E. (2011). Parenting stress and parenting styles in mothers of ADHD with mothers of normal children. Procedia Social and Behavioral Sciences, 30, 1666-1671.

Zarei, J., Rostami, R. \& Ghapanchi, A. (2010). Marital satisfaction in parents of children with attention deficit/hyperactivity disorder in comparison with parents of normal. Procedia Social and Behavioral Sciences, 5, 744747.

Zwi, M., Jones, H., Thorgaard, York, A. \& Dennis, J.A. (2012). Parent Training Interventions for Attention Deficity Hyperactivity Disorder (ADHD) in Children Aged 5 to 18 Years. Oslo: The Campbell Collaboration. 